\title{
Tissue Response of Calcium Polyphosphate in Beagle Dog
}

\author{
SM Yang ${ }^{1,4}$, WH Kim¹, SJ Lee², SY Kim³ , YT Lim³ , JY Lee², \\ YM Lee1, Young K¹, CP Chung ${ }^{1}$, SB Han ${ }^{1}$, SM Choi ${ }^{1}$, IC Rhyu ${ }^{1}$ \\ ${ }^{1}$ Dept. of Periodontology, College of Dentistry, Seoul National University \\ 2 Dept. of Industrial Pharmacy, College of Pharmacy, Ewha Woman's University \\ ${ }^{3}$ School of Materials Engineering, Yeungnam University \\ ${ }^{4}$ Dept. of Periodontology, The Institute of Oral Health Science, Samsung Medical Center
}

\section{Introduction}

Most bone grafts performed today utilize autograft, allograft, and alloplast with moderate clinical success ${ }^{1-3)}$. Autografts have the advantage of optimal biologic incorporation, histocompatibility and little chance of disease transmission. But it has lack of availability in clinical use, and the harvesting of graft tissue may cause patient morbidity. In contrast, allografts get much wider availability and little patient morbidity associated with graft procurement. However, problems with unreliable graft incorporation, immune response, and possible disease transmission represent clear drawbacks to their use. While several synthetic graft materials have also been introduced, most alloplastic materials function primarily as a biocompatible defect filler ${ }^{4}$. Several attempts have been made to resolve these problem use of biodegradable polymers and combination of ceramics with bioactive polymers such as collagen and polylactides ${ }^{5-7)}$. Chitosan is a biodegradable cationic polysaccharide composed of N-acetylglucosamine residues which is known to accelerate wound healing and bone formation ${ }^{8}$. Many previous reports corroborated enhanced wound healing912) and hemostatic effect ${ }^{13-17)}$ of chitosan. It is hypothesized that the major path for chitosan breakage down in vivo is through lysozyme, which acts slowly to depolymerize the polysaccharide ${ }^{18)}$. The biodegradation rate of the polymer is determined by the amount of residual acetyl content, a parameter that can easily be varied ${ }^{8}$.

One possible approach toward addressing the respective problems inherent in autograft and allograft material is employing tissue engineering which is actively researched today. Tissue engineering is a science in which material properties of synthetic compounds are manipulated to enable delivery of an aggregate of dissociated cells into host in a manner that result in the formation of new tissue. Thus the major goal of tissue engineering is in vitro construction of transplantable vital tissue ${ }^{19)}$.

This study was supported by a grant of the korea Health 21 R\&D Project, Ministry of Health \& Welfare, Republic of Korea.(HMP-99E-10-0003) 
The engineering of bone tissue requires appropriate carriers that allow a 3-dimensional distribution of cells. Ishaug et al. suggested several prerequisities for a scaffold material for bone formation ${ }^{20)}$. First, the scaffolding material for bone formation must allow for the attachment of osteoblasts because they are anchorage dependent cells that require a supportive matrix in order to survive. Second the scaffold must provide an appropriate environment for proliferation and function of osteoblasts. Third the scaffold should allow for ingrowth of vascular tissue to ensure the survival of transplanted cells. Fourth, the materials should be biodegradable and its degraded moleculse should be easily metabolized and excreted. Finally it should be processable into irregular 3-dimensional shapes.

Porous alloplastic implants have been studied extensively for their use in oral and maxillofacial applications ${ }^{21)}$. The use of these materials allows for recovery of the cosmetics and continuity of the surrounding bony structures without the concerns associated with the use of autogenic implants. These include but are not limited to increased potential for graft resorption donor site morbidity, and immunogenic reaction to bank bone. Other advantages of porous alloplastic material in periodontal and craniofacial applications include an increase in resistance to separation ${ }^{22)}$. Ceramics, porous block hydroxyapatite(HA), which is one such alloplastic material, has been shown to be an effective implant material in short- and long-term application ${ }^{23)}$. With advances in ceramics technology, the application of calcium phosphate materials have received considerable attention as bone substitutes for several decades. Calcium phosphate as bone substitutes are believed to be biocompatible and osteoconductive when implanted in bone defects ${ }^{24-27)}$. Numerous animal studies provide histologic evidene of the long-term biocompatibility of porous HA and of its favorable interaction with soft tissue and bone ${ }^{28,29)}$. In addition, these studies indicate the lack of an inflammatory response to HA implants ${ }^{30,31)}$.

A substrate such as hydroxyapatite that provides a three-dimensional guideline for bone shape facilitates bony ingrowth and subsequent positional stability as discussed in Wolford et al ${ }^{32,33)}$. The porous structure of HA provides a template for fibrovascular ingrowth which is followed by osteoblast differentiation that results in the deposition of new lamellar bone. Porous material are highly favorable over nonporous materials owing to the accessibility of the interior of the material to tissue ingrowth. If the pores appropriately sized, they can provide a frame work for bone growth into the matrix of the material. Thus, matrices with a normal pore size of $200 \mu$ $\mathrm{m}^{34)}$, resulted in occlusion of pores by migrating cells, while similar scaffolds of $500 \mu \mathrm{m}$ nominal pore size permitted three -dimensional tissue growth in vitro which has led to the convincing demonstrating of new bone growth on the pore walls in vivo by Yoshikawa et al.

Calcium phosphates are generally considered materials of choice as bone substitutes. While calcium phosphate ceramics meet some of the needs for bone replacement they are limited by their inherent stiffness, brittleness and low fatigue properties relative to bone ${ }^{35)}$ and are generally not resorbed during bone remodeling ${ }^{36)}$. The condensed phosphates are very numerous and exist both as crystalline salts and as amorphous glasses. According to the ratio of $\mathrm{Ca}$ and $\mathrm{P}$, condensed phosphates can be divided into three groups: linear polyphosphates, metaphosphates, and ultraphosphates. All varieties are formed by repeated condensation of tetrahedral $\mathrm{PO}_{4-}^{3-}$ groups. Among the many candidates for bioabsorbable or transient implants, the use of bioabsorbable Calcium Polyphosphate(CPP) has twofold advantages over that of the other 
bioabsorbable polymeric materials. that is, $\mathrm{CPP}$ is chemistry similar to natural bone and has higher stiffness. The CPP are controlled the rates of biodegradability by method of preparation and type of $\mathrm{CPP}^{37)}$.

The purpose of this study was to investigate the tissue response and osteo-conduction capability of Calcium Polyphosphate(CPP) as bone graft material and to compare with the semi-automatic histomorphoric new bone formation between CPP and demineralized freeze-dried bone .

\section{Materials and Methods}

\section{Manufacturing Calcium Polyphosphate}

Interconnected porous calcium ployphosphate (CPP) blocks were prepared by condensation of anhydrous $\mathrm{Ca}\left(\mathrm{H}_{2} \mathrm{PO}_{4}\right)_{2}$ (Duksan Chemical Co., Inc.) to form non-crystalline $\mathrm{Ca}\left(\mathrm{PO}_{3}\right)_{2}$. From the latter, an homogenous melt was created by thermal treatment, quenched in distilled water, and the block was then milled to produce CPP powder ${ }^{38)}$. Which was added with $\mathrm{Na}_{2} \mathrm{O}$ addition of $\mathrm{Na}_{2} \mathrm{O}$.

CPP granules were prepared according to the pore size $45 \mathrm{ppi}$. Pore size of $\mathrm{CPP}(45 \mathrm{ppi})$ is approximately $450-550 \mu \mathrm{m}$.

The CPP granules with chitosan was prepared by use of CPP powder. The each powder of CPP, $\mathrm{CaSO}_{4}$, and chitosan were mixed into weight ratio 5:1:1 in 5\% chitosan solution as binder. The mixed compound was penetrated into mesh which pore size is $800 \mu \mathrm{m}$ and then dried in the fan oven. The size of CPP granule with chitosan was 300-500 $\mu \mathrm{m}$.

\section{Animal experiments}

The 3 year-old female adult beagle dog used were bred exclusively for biomedical studies and bucco- gingival health was checked before experimentation, and all teeth of the dog were preliminarily scaled and polished under general anesthesia. Antibiotic treatment with spiramycin and metronidazole was given for 5 days.

surgical procedures ${ }^{39)}$. All surgical procedures were performed under general anesthesia with intramuscular rompun ${ }^{\circledR}(1.5 \mathrm{~mL} / \mathrm{kg})$ followed by anesthesia with $\operatorname{ketar}^{(1)}(5 \mathrm{mg} / \mathrm{kg})$. During surgery, the animals received lactated Ringer's solution and $1 \mathrm{~g}$ of cephalosporin antibiotic perfused intravenously. The extractions were performed on right and left second, third and fourth mandibular premolars and on right and left second and third maxillary premolars.

Thus, 10 teeth were extracted per animal. as premolar teeth are biradicular, 20 alveolar extraction sites were available for bone filling. After sulcular incisions, full- thickness buccal and lingual mucoperiosteal flaps were raised. Gingival incisions were extended mesially from the canine and distally to the molar teeth. A vertical interradicular section was performed with a dental bur under sterile irrigation to separate all teeth into 2 pieces and avoid root and alveolar cortical bone fracture during extraction. Each root was carefully mobilized with a dental elevator and then gently extracted with a dental forceps.

All alveolar sites were checked after extraction and thoroughly debrided with a dental curet to remove the periodontal ligament. Extraction sites were grafted with biomaterial or left unfilled; i.e, the mesial socket of a tooth was left unfilled and the distal socket filled with the composite biomaterial. The CPP granules with chitosan and CPP granules with $\mathrm{Na}_{2} \mathrm{O}$ were injected into the extraction socket in a retrograde manner from the bottom of the socket to the top of the alveolar crest. Material was gently packet into place (no overpacking), and excess 
material was removed from unfilled sites. The connective tissue surfaces of the buccal and lingual flap margins were carefully joined together, and nonresorbable hermetic sutures were performed.

Antibiotic treatment by intramuscular injection of cephalosporin( $15 \mathrm{mg} / \mathrm{kg}$, b.i.d )was continued for 48hours after surgery. The animals were checked daily and fed with a soft consistency diet. Sutures were removed under short general anesthesia 2 weeks after implantation ( day 14) and a normal diet was then given.

The animals were sacrificed 3months after implantation (day 90) by intravenous injection of overdosed sodium pentobarbital.

Sample preparation. Mandibular and maxillary osseous segments were immediately dissected from the animals and fixed in paraformaldehyde solution. They were fixed with thin metal pins before radiographs were performed to localize each socket. The sockets were individually separated by cutting into the intra and interdental septa with a diamond saw, according to the pins' position. Each socket was dehydrated in graded ethanol and embedded in a glycolmethylmethacrylate resin.

\section{Histological evaluation and Bone ingrowth measurements}

Both treated and control mandibular and maxillary sites were histologically evaluated with light microscopy. For each socket, $30 \mu \mathrm{m}$ thick sections were cut with a hard tissue microtome along the long axis of the root implantaton site and then multiple-stained for light microscopy observations.

The surface of the resin block obtained from the centarl area of the socket was prepared for LM observations Bone ingrowth was investigated and compared in filled and control mandibular and maxillary sites and quantitatively evaluated using a Image Access (Bildanalysis System, Sweden). Results are given as the percentages of newly formed bone in mandibular and maxillary extraction sites.

\section{Statistical analysis}

Differences in new bone formation between CPP
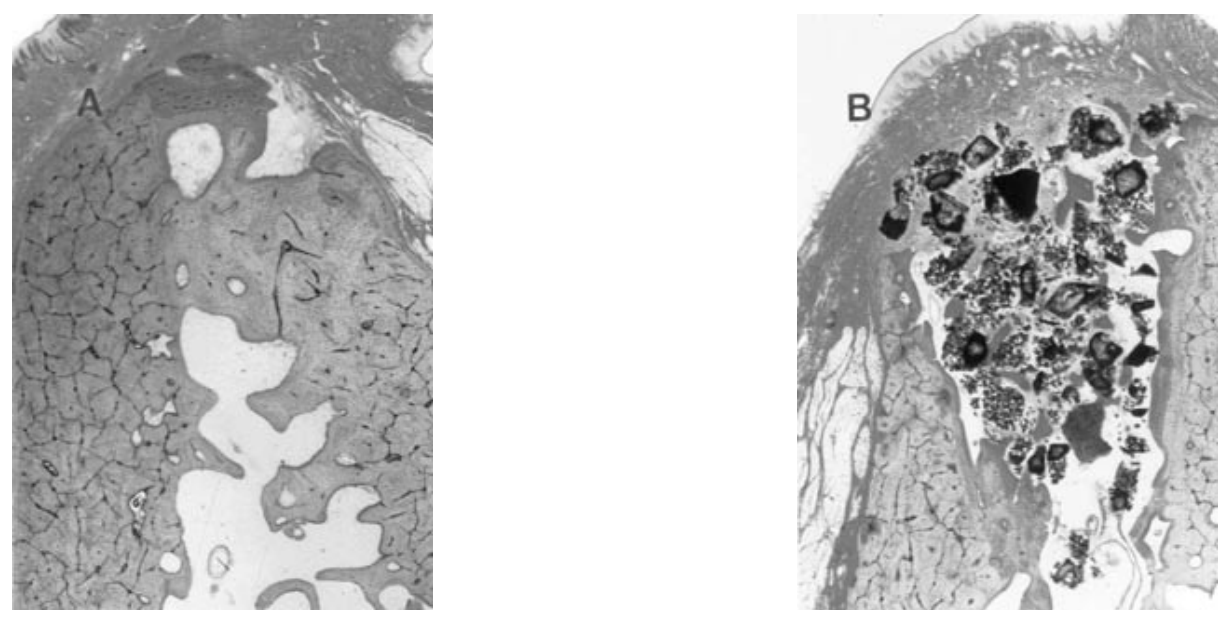

Figure1. CPP granules with $\mathrm{Na}_{2} \mathrm{O}$ and control after 3months of healing in extraction site. Figure illustrates the whole defect. (A) control site (multiple stain, original magnification $\times 20$ ) (B) CPP granules with $\mathrm{Na}_{2} \mathrm{O}$ 

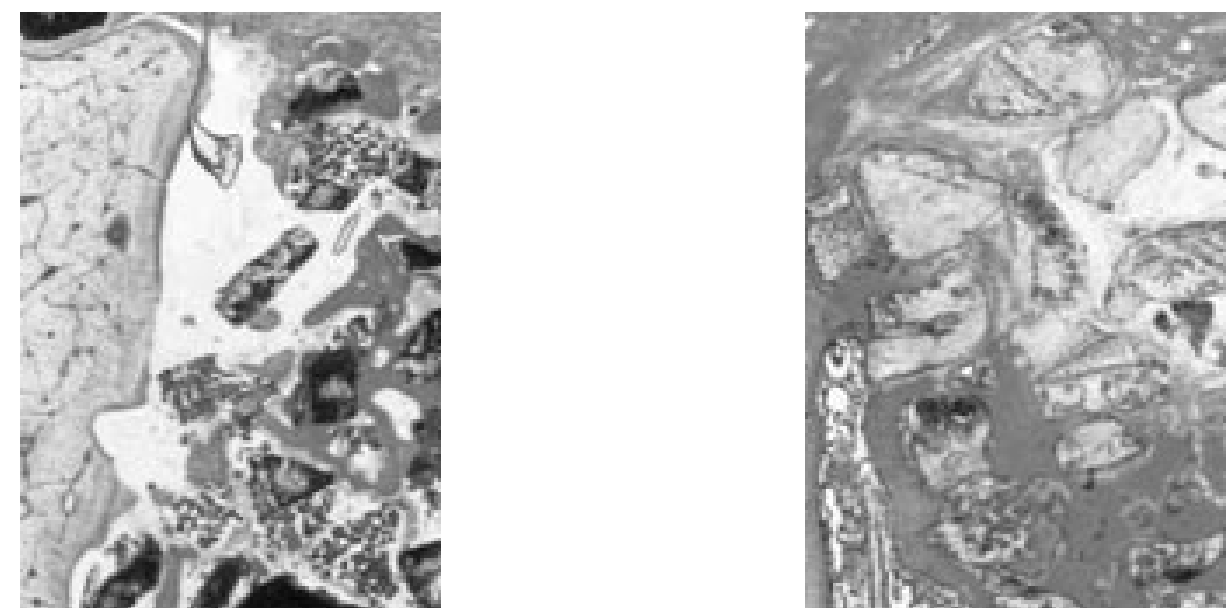

Figure2. bone formation around CPP granules (A) CPP granules with chitosan and(B) CPP granules with $\mathrm{Na}_{2} \mathrm{O}$. (multiple stain, original magnification $\times 20$ )

granules with chitosan and CPP granules with $\mathrm{Na}_{2} \mathrm{O}$ and demineralized freeze-dried bone sites were studied for statistical purposes with one-way ANOVA test. $\mathrm{P}$ values $<0.05$ were considered statistically significant.

\section{Results}

\section{Histologic findings}

All control and experimental sites healed uneventfully with no clinical evidence of inflammatory response to the $\mathrm{CPP}$ implants and DFDB. Histologically, although no quantitative measurements were made, the amount of newly formed bone appear to be greater in specimens with $\mathrm{CPP}$ granules with $\mathrm{Na}_{2} \mathrm{O}$ as compared to the control sites. This is shown in figure 1 which depicts acclerated new bone formation around the CPP granules and no fibrous encapsulation (fig2).

Howerver, the tissue appears to demonstrate a decrease in osteoblastic activity and some of the CPP granules were simply surrounded with fibrous connective tissue.

The unresorbed CPP granules with $\mathrm{Na}_{2} \mathrm{O}$ and CPP granules with chitosan showed an irregular surface indicating that resporption or dissoultion process of the CPP granules took place prior to laying down of mineralized bone matrix. This is in contrast with the relatively smooth appearing surface which contacted directly newly formed bone around CPP grnaules (fig3). The bone showed large narrow spaces with no evidence of active bone formation. As the proportion of $\mathrm{Na}_{2} \mathrm{O}$ increases, osteoclastic activity also

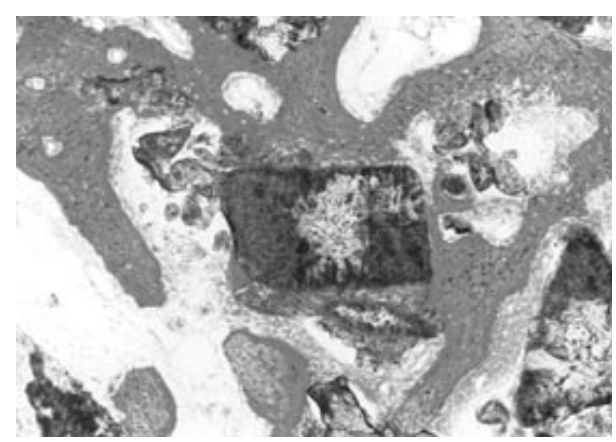

Figure3. CPP granules have smooth and irregular surface (multiple stain, original magnification $\times 100)$ 

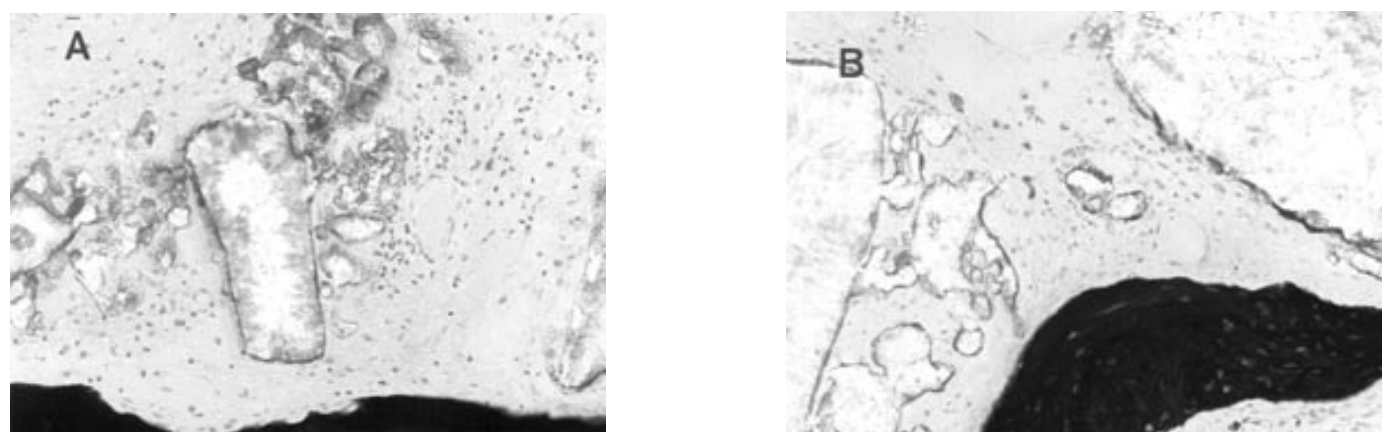

Figure 4. Tissue response of CPP in extraction site. A few inflammatroy cells infiltrate but no significant adverse reaction is seen. Multinucleated giant cells were shown. (A) CPP granules with chitosan (B) CPP granules with $\mathrm{Na}_{2} \mathrm{O}$. (H\&E stain, original magnification $\times 200$ )

increases with concomitting CPP granules resoption as evidenced by the presence of munerous multinucleated giant cells (fig4) and CPP granules which have rough surface present in the implant site.

\section{Measurement of newly formed bone}

The one-way ANOVA showed that all the treatments produced statistically significant higher gain in new bone formation than did the control groups ( $p<0.05)$ (table 1). But the analysis showed that, for implanted sites comparisons, there is no significant difference between experimental sites with implant

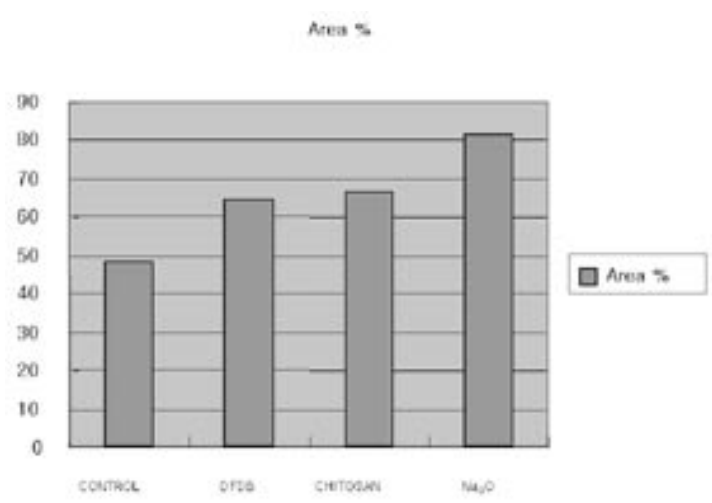

Figure5. Area \% of new bone formation in groups. material(fig. 5). Between the CPP granules with chitosan and $\mathrm{CPP}$ granules with $\mathrm{Na} 2 \mathrm{O}$, there is also no significant difference. In experimental sites, DFDB , CPP granules with chitosan and CPP granules with $\mathrm{Na}_{2} \mathrm{O}$ are also showed new bone formation but, there is no significant difference between groups.

\section{IV.Discussion}

Periodontal regeneration therapy with bone-substituting materials has gained favorable clinical efficacy by enhancing osseous regeneration in peri-

Table 1

\begin{tabular}{cc}
\hline Group & \% of Regenerated Area \\
\hline 1 & $44.04 \pm 4.7^{*}$ \\
2 & $72.64 \pm 6.1 \#$ \\
3 & $66.48 \pm 1.0 \#$ \\
4 & $80.46 \pm 5.7 \#$ \\
\hline
\end{tabular}

*: Mean \pm S.D.

\# : There were significant differences $\%$ area of new bone formation between group 1 and the other groups $(\mathrm{p}<0.05)$

Group1 : Control

Group2 : Demineralized freeze dried bone (DFDB)

Group3 : CPP granule with chitosan

Group4 : $\mathrm{CPP}$ granule with $\mathrm{Na}_{2} \mathrm{O}$ 
odontal bony defect ${ }^{40-48)}$. As bone substituting materials, bone powder ${ }^{40,41)}$, calcium phosphate ceramic $^{42,43)}$, modified forms of hydroxyapatite ${ }^{44,45)}$, and hard tissue replacement polymer ${ }^{46-48)}$ have demonstrated their periodontal bony regenerative potency. Bone-substituting materials should fulfill several requirements such as biocompatibility, osteogenecity, malleability, biodegradability ${ }^{40-42,46)}$. However, these materials revealed some drawbacks including bone resorption,immune response, disease trasmission, low biodegradability, poor adaptation.

Many investigators reported encouraging clinical results of several synthetic grafts, but histologically the grafts tend to be encapsulated by connective tissue with little bone formation. This is likely to be true with not only non-absorbable materials but also absorbable materials. At present, therefore, most of synthetic graft materials were considered primarily as biocompatible defect filler ${ }^{4}$. In this point, regardless of additional component, CPP granules might exhibit biocompatible, highly osteoconductive characteristics. They might be also considered promising candidates as a scaffold for tissue engineered bone formation. But they exhibited very slow degradation rate. That may pose a problem for the replacement of these devices with new bone and may alter the mechanical properties of the newly formed bone. In this study, there is no result about bioabsorbable properties of CPP granules, so further investiogations are to fulfilled.

Since chitosan can be well adapted to inorganic materials such as calcium phosphate, tricalcium phosphate and hydroxyapatite containing chitosan paste has been introduced as a self-setting material for bony lesion ${ }^{50-55)}$. Also in present study CPP granules were employed for enhancement of material properties and osteocondutivity of chitosan matrix. In histologic finding and histomorphometric finding, no significant differences between CPP granules with $\mathrm{Na}_{2} \mathrm{O}$ and $\mathrm{CPP}$ granules with chitosan were found in matrix degradation and the amount of induced new bone by the two. These findings indicate that the addition of chitosan to CPP granules problably does not evoke any adverse effects to degradation of the matrix or healing of defect, and also does not serve any additional osteoconductive effect.

The susceptibility of chitosan to depolymerization under the catalytic action exerted by lysozyme is dependent on the molecular size of the polymer or degree of deacetylation. Thus, biodegradation rate of the chitosan matrix could be varied by controlling the amount of residual acetyl content. In present histologic examination of extraction sites healing, newly formed osseous tissues infiltrated into and were mingled with the matrices being degraded simultaneously. In this points, these matrices might show acceptable degradation rate as bone replacement graft materials, compraed to CPP granules itself.

The knowledge of the degradation mechanism is far from complete, but it is generally known that the hydrolytic degradation of CPP is due to the disruption of hydrolyzable -P-O-P bonds in CPP by water molecules ${ }^{56)}$. Bunker reported on the mechanism and kinetics of dissolution for polyphosphate ceramics and that the dissolution of polyphosphate ceramics is congruent independent of ceramic composition, the $\mathrm{pH}$, or the sample surface/solution volume ratio(S/V). It occurs by the hydration of the glass surface and release of polyphosphate chains into the solution. It is known that protons enhance the dissolution rates of polyphosphate ceramics, but the hydrated polyphosphate released in solution limits the dissolution ${ }^{57)}$. Owing to the progressive increase in ionic strength, an increase in electrostatic interactions in the hydrated layer occurs, that results in a 
decrease of the dissolution rate. In this study, addition of $\mathrm{Na}_{2} \mathrm{O}$ may increase the biodegradation rate initially, but during the degradation, that retards the biodegradation. So optimal percentage of $\mathrm{Na}_{2} \mathrm{O}$ will be investigate in future study.

In this study, regardless of its additive components, CPP granules showed osteoconductivity and biocompatibility, but they exhibited very slow degradation rate. CPP is available in various forms and its degradation rate is controllable, so in future study, we investigate the optimal forms of CPP and additive components to increase the degradation rate.

\section{Conclusion}

1. The CPP granules contact to new bone directly.

2. The new bone formation was found in CPP granules with chitosan, CPP granules with $\mathrm{Na}_{2} \mathrm{O}$ and DFDB group

3. There is significant difference between CPP granules with chitosan, CPP granules with $\mathrm{Na}_{2} \mathrm{O}$ and control group ( $\left.\mathrm{p}<0.05\right)$.

4. There is no significant difference between CPP granules with chitosan and CPP granules with $\mathrm{Na}_{2} \mathrm{O}$ (p>0.05).

\section{References}

1. Froum SJ, Thaler R, Scopp IW, Stahl SS: "Osseous autograft, I. Clinical response to bone blend or hip marrow autograft." J Periodontol 46:515-521,1975.

2. Schallhorn RG: "Present status of osseous grafting procedures." J Periodontol 48:570-576,1977.

3. Mellonig JT: "Decalcified freeze-dried bone allograft as an implant material in human periodontal defect." Int J Periodont Restorative Dent 4: 41-55,1984.
4. Garrett S: "Periodontal regeneration around natural teeth." Ann Periodontol 1: 621-666, 1996.

5. Horisaka Y, Okamoto Y, Matsumoto N, Yoshimura Y, Hirano A, Nishida M, Kawada J, Yamashita, Takagi T,: "Histological changes of implanted collagen material during bone induction." J Biomed Mater Res 28:97-103,1994.

6. Robinson BP, Hollinger JO, Szachowicz EH, Brekke J: "Calvarial bone repair with porous D,Ll-polylactide." Otolaryngol Head Neck Surg 112:707-13,1995.

7. Rovira A, Amedee J, Bareille R, Rabaud M: "Colonization of a calcium phosphate/elastinsolubilized peptide-collagen composite material by human osteoblast." Biomaterials 17:1335540,1996 .

8. Muzzarelli RA: "Biochemical significance of exogenous chitins in animals and patients." Carbohydr Polym 20:7-16,1993.

9. Muzzarelli RA, Baldassarre V, Conti F, Ferrara P, Biagini B: "Biological activity of chitosan: Ultrastructural study." Biomaterials 9:247253,1988.

10. Mallette WG, Quigley H, Adickes ED: "Chitin in nature and technology." in :Muaazrelli R, Jeuiaux C, Gooddy GW, eds. "Chitosan effect in nature and technology." Plenum Press, New York, 1986

11. Allen GG, Alttan AC, Bensinger RE, Ghosh DA, Hirabayashi Y, Neogi AN: "Biomedical applications of chitin and chitosan." in: Zikakis JP, ed "Chitin, Chitosan and related enzymes", Academic Press, Inc New York, 1984

12. Van der lei B, Wildevuur GH : "Improved healing of microvascular pttfe prosthesis by induction of a clot layer: An experimental study in rat." Plast Reconst Surg 84: 960-968,1989.

13. Mallette WG, Quigley H, Gaines RD, Johnsoon ND, Rainer WG: Chitosan : "A new homostatic." 
Ann Thorac Surg 36;55-58,1983

14. Brandenberg G, Leibrock LG, Shuman R, Malette WG, Quiglery H: Chitosan : "A new topical hemostatic agent for diffuse capillary bleeding in brain tissue." Neurosurg 15:9-13,1984

15. Kind GM, Bind SD, Staren DE, Templeton AJ, Economou SC: "Chitosan: Evaluation of a new hemostatic agent." Curr Surg 47:37-39,1990

16. Klokkevold PR, Lew DS, Ellis DG, Bertolami CN: "Effect of chitosan lingual hemostasis in rabbit." J Oral Maxillofac Surg 49: 858-863,1991

17. Kolkkevold PR, Subar B, Fukayama H, Bertolami CN: "Effect of chitosan lingual hemostasis in rabbit with platelet dysfuction induced by epoprostenol." J Oral Maxillofac Surg 50:4145,1992

18. Taravel MN, Domard A: "Relation between the physiochemical characteristics of collagen and its interactions with chitosan: I", Biomaterials 14:930-938,1993

19. Vacanti CA, Vacanti JP: "Bone and cartilage reconstruction with tissue engineering approaches." Otolryngol Coin North Am 27:263-276,1994

20. Ishaug SL, Crane GM, Miller MJ, Yasko AW, Yasxemski MJ, Mikos AG: "Bone formation by three-dimensional stromal osteoblsat culture in biodegradable polymer scaffolds." J Biomed Mater Res 36: 17-28,1997.

21. Wardrop RW, Wolford LM: "Maxillary stability following downgraft and/or advancement procedures with stabilization using rigid fixation and porous block hydroxyapatite implants." J Oral Maxillofac Surg 47:336-342,1989.

22. Bagambisa FB, Joos U, Shilli W: "Mechanism and structure of the bond between bone and hydroxyapatite ceramics." J Biomed Mater Res 27:1047-1055,1993.

23. Nunes CR, Simske SJ, Sacdeva R, Wolford LM: "Long-term ingrowth and apposition of porous hydroxyapatite implants." J Biomed Mater Res 36:560-563,1997.

24. de Groot K: "Macropore tissue ingrowth : A quantitative and qualitative sutdy on hydroxyatpattie ceramic." Biomaterials 7:137-143,1986.

26. Muller-mai CM, Voigt C, Gross U: "Incorporation and degradation of hydroxyapatite implants of different surface roughness and surface sturcture in bone." Scan Microsc 4: 501-511,1991.

27. Boyde A, Corsi A, Quarto R, Cancedda R, Bianco $\mathrm{P}$ : "Osteoconduction in large macroporous hydroxyapatite ceramic implants: Evidence for an complementary integration and disintegration mechanism." Bone, 24:579-589,1999.

28. Mehlisch DR, Leider AS, Roberts WE: "Histologic evaluation of the bone/graft interface after mandibular augmentation with hydroxylapatite /purified fibrillar collagen composite implants." Oral Surg Oral Med Oral Patho, 70:685-692,1990.

29. Yolmes RE, Wardrop RW, Wolford LM: "Hydroxylapatitie as a bone graft substitute in orthognathic surgery: Histology and histomeric findings." J Oral Maxilloac Surg, 46:661671,1988.

30. Jarcho M: "Calcium phosphate ceramics as hard tissue prothetics." Clin Orthop 157:259-278,1981.

31. Ducheyne P: Bioceramics: "Material characteristics versus in vivo behavior." J Biomed Mater Res Appl Biomater. 21a:219-236,1987.

32. Ayers RA, Wolford LM, Bateman TA, Ferguson VL, Simske SJ: "Quantification of bone ingrowth into porous block hydroxyapatite in humans." J Biomed Mater Res 47(1):54-59,1999

33. Nunes CR, Simske SJ, Sachdeva R, Wolford LM: "Long-term ingrowth and apposition of porous hydroxyapatite implant." J Biomed Mater Res 36: 560-563,1997.

34. Rout PG ,Tarrant SF, Rrame JW, Davies JE: in "Biomaterials and clinical applications", edited 
by Pizzoferrato A, Marchetti PG, Ravaglioli A, Lee AJ elsevier, Amsterdam 1987

35. Hench IL, in "Biomaterial Science." edited by Ratner BK, Hoffman AS, Schoen FJ, Lemons JE Academic Press. Boston MA 1996

36. Davies JF, Brady J. in "Handbood of Bioactove Ceramics 2" edited by Yamamuro T, Hench LL, Wilson J CRCc Press Boca-Ration FL 1990

37. Andriano KP, Daniels AJ, "Biocompatibility and mechanical properties of an totally absorbable composite material for orthopedic fixation devices" J Appl Biomat 3: 197-206,1992.

38. Kim S: "Bioresorbable calcium metaphosphate ceramics: I. Prepatrtion and Preliminary in vitro study." Biomaterial Research 2:48-52,1998.

39. Gauthier O, Boix D, Grinamdi G, Aguado E, Bouler JM, Weiss P, Daculsi G: "A new injectable calcium phosphate biomaterial for immediate bone filling of extraction sockets: A preliminary study in dogs." J Periodontol 70:375-383,1999.

40. Peltzman B, Bowers GM, Reddi AH, Berfquist JJ. "Treatment of furcation involvement with fibronectin and intraoral autogenous bone grafts: Preliminary observation." Int J Periodont Restorative Dent 8(5):51-63,1988.

41. Sepe WW, Bowers GM, Lawrence JJ. "Clinical Evaluation of freeze-dried bone allografts in periodontal osseous defect, part II." J Periodontol 60:9-14,1989.

42. Legeros RZ: "Calcium phosphate materials in restorative dentisry: a review." Adv Dent Res 2:164-180,1988.

43. Peplassi EM, Bissada NF, Greenwell H, Farah CF: "Doxycycline-tricalcium phosphate composite grafrt facilitates osseous healing in advanced periodontal frurcation defects." J Periodonol 62:106-115,1991.

44. Lin FH, Lin CC, Liu HC, Huang YY, Wang CY, Lu CM: "Sintered porous -bioactive glass and hydroxyapatite as bone subsittute." Biomaterials 15(13):1087-1098,1994.

45. Kenney EB, Lekovic V, Elbaz JH, Kovbawvvic K, Caranza FR, Takei JR : "The use of a porous hydroxyapatite implant in periodontal defects. II. Treatment of class II furcation lesions in lower molars." J periodontol 59:67-72,1988.

46. Yukna RA: "Clinical evaluation of HTR polymer bone replacement grafts in human mandibular class II molar furcations." J Periodontol 65:342349,1994.

47. Suzuki JB, Babcock-goodmans, Phillips B: "Comparison of clinical healing of human periodontal defects with HTR synthetic grafts." J Dent Res 68:409(abstr.1822),1989.

48. Amler MH, Legeros RZ: "Hard tissue replacement (HTR)polymer as an implant material." J Biomed Mater Res 24:1079-1089,1990.

49. Cole J, Arlett CJ: "Mutaginicity testing." IRL Press, Oxford. 1984

50. Ito M, Yanagishi T, Yagasaki H, Kafrawy AH: "In vitro properties of a chitosan-bonded bone-filling paste: studies on solubility of calcium phosphate compounds." J Biomed Mater Res 32:9598,1996.

51. Ito $\mathrm{M}:$ "In vitro porperties of a chitosan-bonded hydroxyapatite bone filling paste." Biomaterials 12:41-45,1991.

52. Kawakami T, Antoh M, Hasegawa H, Yamagishi H, Ito M, Eda S: "Experimental study on osteoconductive properties of a chitosan-bonded hydroxyapatite bone filling paste." Biomaterials 13:759-763,1992.

53. Ito M, Miyazaki A, Yamagishi T, Yagasaki H, Hashem A, Oshid Y: "Experiomental development of a chitosan-bonded beta-tricalcim phosphate bone filling paste." Biomed Mater Eng 4:439-449,1994.

54. Ito M, Yamagishi T, Sugai T: "Experimental 
development of a chitosan-bonded hydroxyapatite bone filling paste." Shika Zairyo Kikai 9:608-616,1990.

55. Maruyama $M$, Ito $M$ : "In vitro properties of a chitosan-bonded self hardening paste with hydroxyapatiote granules." J Biomed Mater Res 32:527-532,1996.
56. Corbridge DE: Phosphorus : "An outline of its chemistry, Biochemistry and Technology." 5th Ed., Elsevier, 1995

57. Delahaye F, Montagne L, Palavit G, Touray JC, Baillif P: "Acid dissolution of sodium-calcium metaphosphate glasses." J of Non-Cryst Solids 242:25-32,1998. 


\title{
비글견에서의 Calcium Polyphosphate의 조직반응에 관한 연구
}

\author{
양승민 ${ }^{1}$ · 김우현 1 - 이승진 2 · 김석영3 · 임윤탁 ${ }^{3}$ - 이주연2 \\ 이용무1 · 구영1 · 정종평1 · 한수부1 · 최상묵1 · 류인철1 \\ 1서울대학교 치과대학 치주과학교실 \\ 2이화여자대학교 약학대학 약학과 \\ 3영남대학교 공과대학 재료금속공학과 \\ 4삼성의료원 치과진료부 치주과
}

치주조직 재생을 도모하기 위한 전통적인 시술방법으로 여러가지 골이식재를 이용한 골이식술이 이용되고 있다. 이번 실험의 목적은 골형성을 위한 재료로 Calcium Polyphosphate(CPP)를 사용하여 비글견에서의 조직 반응과 골유도성을 보는 것이고 또한 다른 이식재들간에 신생골의 형성에 어느정도 영향을 주는 가를 알아보 는 것이다. 이번 실험에 사용된 $\mathrm{CPP}$ 는 무수 $\mathrm{Ca}\left(\mathrm{H}_{2} \mathrm{PO} 4\right)$ 를 condensation하여 무결정의 $\mathrm{Ca}\left(\mathrm{PO}_{3}\right)_{2}$ 를 얻고 이를 용 율하고 냉각시킨 후 분쇄하여 얻은 것으로 3세된 비글견에 이식하여 관찰하였다. 조직학적으로 CPP granule의 경우는 키토산이나 $\mathrm{Na}_{2} \mathrm{O}$ 를 넣은 경우 모두 bone 의 ingrowth가 관찰되었고 다른 섬유조직의 개재를 볼수 없었 다 동결탈회건조골을 넣은 경우에는 주위로 골형성 보이지 않았고 단지 섬유성 조직이 관찰 되었다. 아무것도 넣지 않은 경우에 비해서 동결탈회건조골이나 키토산, $\mathrm{Na}_{2} \mathrm{O}$ 를 넣은 $\mathrm{CPP}$ granules 경우에 더 많은 비율로 신생 골의 양이 나타나는 것을 볼수 있었다. 아무것도 넣지 않은 대조군과 이식재를 넣은 군간에는 유의성이 있는 것으로 나타났고(p<0.05). 또한 CPP granules with chitosan과 CPP granules with $\mathrm{Na} 2 \mathrm{O}$ 사이에는 신생골의 형 성에 유의성이 없었다. 이것으로 보아 CPP granules with chitosan과 CPP granules with $\mathrm{Na}_{2} \mathrm{O}$ 는 모두 골유도성 이 있고 신생골의 형성을 촉진하므로 치주질환으로 인한 골결손 부위에 사용할 수 있는 재료로 우수한 특성을 지닌다고 사료된다.

주요어 : Calcium Polyphosphate, 골 유도성, 키토산, $\mathrm{Na} 2 \mathrm{O}$, 신생골 형성, 조직공학 